\title{
Synthesis and Evaluation of Anticancer Activity of 1, 3, 4-0xadiazole Derivatives against Ehrlich Ascites Carcinoma Bearing Mice and Their Correlation with Histopathology of Liver
}

\author{
Partha Pratim Roy¹, Shalini Bajaj', Tapan Kumar Maity², Jagadish Singh ${ }^{1 *}$ \\ ${ }^{1}$ Institute of Pharmaceutical Sciences, Guru Ghasidas Vishwavidyalaya, Koni, Bilaspur, Chhattisgarh, INDIA. \\ ${ }^{2}$ Department Of Pharmaceutical Technology, Jadavpur University, Kolkata, West Bengal, INDIA.
}

\begin{abstract}
A series of 2, 5-disubstituted 1, 3, 4-Oxadiazole derivatives (4A-4G) have been synthesized with the help of different aromatic benzaldehyde and final compounds were characterized by FT-IR, ${ }^{1} \mathrm{H}$ NMR and Mass spectroscopy. The anticancer study was investigated against Ehrlich Ascites Carcinoma (EAC) bearing albino mice. The synthesized (4A-4G) compounds were administered intraperitoneally at dose of $20-25 \mathrm{mg} / \mathrm{kg}$; body weight per day for 7 days after 24 hour of tumor inoculation in mice. The standard compound used was 5-FU (20 mg/kg; body, weight). Synthesized compounds (4A-4G) remarkably decreased the body weight, tumor volume, packed cell volume, viable cell count and increased in tumor weight (\%) inhibition, tumor cells (\%) inhibition, the life span, nonviable cell count of EAC tumor bearing mice when compared with the control group. The liver section of EAC treated control group (II) was compared with the drug treated groups (III-X). The histopathological observations of test groups suggested that normal architecture of liver nucleus, parenchyma, and hepatic cells were regenerated, which was damaged in EAC control group. All the synthesized compounds (4A-4G) showed significant anticancer activity in EAC bearing mice which encourages us to develop/improve similar other compounds and test them for their anticancer activity.
\end{abstract}

Key word: Synthesis, 1, 3, 4 oxadiazole, EAC cell, Anticancer activity, FT-IR, NMR.

\section{INTRODUCTION}

Cancer ranked second to cardiovascular disease as a cause of mortality it is likely to become the most common disease in the near future. ${ }^{1}$ In modern medicine, chemotherapy, radiotherapy and surgery are the chief modes of cancer treatment. Chemopreventive agents have a narrow margin of safety and the therapy may fail due to drug resistance and dose limiting toxicities, which may severely affect the host normal cells. ${ }^{2}$ Therefore, identification of novel potent, less toxic and selective mechanism of action anticancer agents remains one of the most imperative health problems. ${ }^{3}$

1,3,4-Oxadiazoles are an important class of heterocyclic compounds ${ }^{4}$ with a broad range of biological activities such as anti-inflamma- tory, analgesic and ulcerogenicity, ${ }^{5}$ apoptosisinducer, ${ }^{6}$ antimycobacterial, ${ }^{7}$ antifungal, ${ }^{8}$ antitumor, ${ }^{3,6,9}$ P-Glycoprotein Inhibitors, ${ }^{10}$ pesticides and insecticides, ${ }^{11}$ 4-Hydroxylase Inhibitors, ${ }^{12}$ anticonvulsant activity ${ }^{13}$ etc.

Moreover, it is considered that the presence of toxophoric $-\mathrm{N}=\mathrm{C}-\mathrm{O}-$ linkage $^{14}$ in 1,3 , 4-oxadiazole ring might be responsible for their potent pharmacological activities. Further1, 3, 4-oxadiazole heterocyclic are very good bioisosters of amide and ester functionalities with substantial improvement in biological activity by participating in hydrogen bonding interactions with different receptor. $^{15,16}$
Submission Date: 30-08-2016; Revision Date: 17-11-2016; Accepted Date: 23-11-2016

DOI: 10.5530/ijper.51.2.31 Correspondence: Dr. Jagadish Singh, Assistant Professor, Institute of Pharmaceutical Sciences, Guru Ghasidas Vishwavidyalaya, Koni, Bilaspur, Chhattisgarh, INDIA.

E-mail: jagadishpharm09@ gmail.com 
Schiff bases containing the $>\mathrm{C}=\mathrm{N}$ group are known to have antitumor activity, more of this compounds have been synthesized in order to find greater antitumor activity. ${ }^{17}$ Thus the present investigation was designed to report some new derivatives of oxadiazole containing $>\mathrm{C}=\mathrm{N}$ group at its 2 position. Considering the potential of this class of compounds some new 2, 5, disubstituted 1, 3, 4-oxadiazole derivatives were synthesized (4A-4G) as showed in Scheme -1, studied for their anticancer activity and histopathological study of liver was performed.

\section{Chemistry}

Semicarbazone (2A-2G) were synthesized by using different aromatic aldehyde $(1 \mathbf{A}-1 \mathbf{G})$, semicarbazide hydrochloride and sodium acetate. (Vogel's, 1996).Then 2-Amino-5-aryl-1, 3, 4-oxadiazole (3A-3G) was prepared by using Semicarbazone (2A-2G), sodium acetate and bromine in glacial acetic acid with the help of Magnetic stirring. 2-Amino-5-aryl-1，3，4-oxadiazoles were refluxed with required aromatic aldehyde (5-6 hours) in ethanol to form final Schiff bases of 2-amino-5-aryl-1, 3, 4-oxadiazoles (4A-4G) derivatives then the final compound was dried and recrystallized from alcohol. The structures of these compounds were characterized by FT-IR, ${ }^{1} \mathrm{H}$ NMR and LC MS/MS Mass spectroscopy.

\section{MATERIALS AND METHODS}

\section{General}

All the chemical (synthetic grade) were procured from Merck, SRL and SD Fine Chemicals. Melting points were determined in open glass capillaries and are uncorrected (VEEGO, VMP-DS). The purity of compounds was checked by TLC on micro plates using Silica-gel-G, solvent system chloroform: methanol (6:1) with detecting agent. Infrared spectra in $\mathrm{KBr}$ were recorded on Shimazdzu 470 Infrared Spectrophotometer. ${ }^{1} \mathrm{H}$ NMR spectra were recorded on a Brucker DPX $(300 \mathrm{MHz})$ NMR spectrometer in DMSO- $\mathrm{d}_{6}$ using TMS as an internal reference, chemical shifts are expressed in ( $\mathrm{ppm})$ and mass were recorded on (API-2000) LCMS/MS. All the compounds have given satisfactory ${ }^{1} \mathrm{H}$ NMR, Mass and FT- IR spectra.

\section{Synthesis}

\section{Semicarbazone [2A-2G]}

Semicarbazones were synthesized by using different aromatic aldehyde (1A-1G) (0.5g), semicarbazide hydrochloride $(1.0 \mathrm{~g})$ and sodium acetate $(1.50 \mathrm{~g})$ were taken in $100 \mathrm{ml}$ conical flask and dissolved in $30-40 \mathrm{ml}$ of distilled water. After half an hour stirring, the precipitate was filtered and recrystallized from alcohol. (Vogel's, 1996).

\section{2-Amino-5-aryl-1, 3, 4-oxadiazoles [3A-3G]}

Semicarbazone $(2 \mathbf{A}-2 \mathbf{G})(0.01 \mathrm{M})$ and sodium acetate $(0.02 \mathrm{M})$ were dissolved in $30-40 \mathrm{ml}$ of glacial acetic acid taken in a $(100 \mathrm{ml})$ round-bottomed flask equipped with a separating funnel for the addition of bromine. Bromine $(0.7 \mathrm{ml}$ in $5 \mathrm{ml}$ glacial acetic acid) was added drop by drop, while stirring magnetically. After half an hour stirring, the solution was poured on crushed ice. The resulting solid was separated, dried and recrystallized from aldehyde free ethanol. ${ }^{18}$

\section{Schiff bases of 5-aryl-2-substituted-1, 3, 4-oxadiazoles [4A-4G]}

A solution of [3A-3G] $(0.01 \mathrm{M})$ was taken in $20 \mathrm{ml}$ alcohol a round-bottomed flask. Required aldehyde $(0.01 \mathrm{M})$ dissolved in $15 \mathrm{ml}$ alcohol was then added to it. The mixture was refluxed for 5-6 h. The volume of alcohol was reduced to half by distillation under reduced pressure. The resulting solution was poured on crushed ice. The precipitate was separated, dried and recrystallized from alcohol. ${ }^{9}$

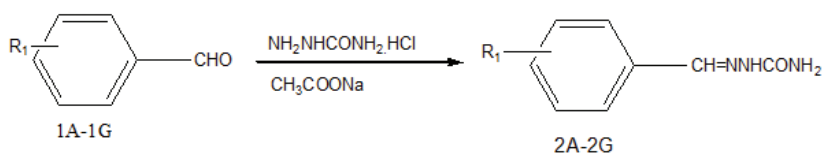

$\mathrm{Br}_{2} / \mathrm{CH}_{3} \mathrm{COOH}$

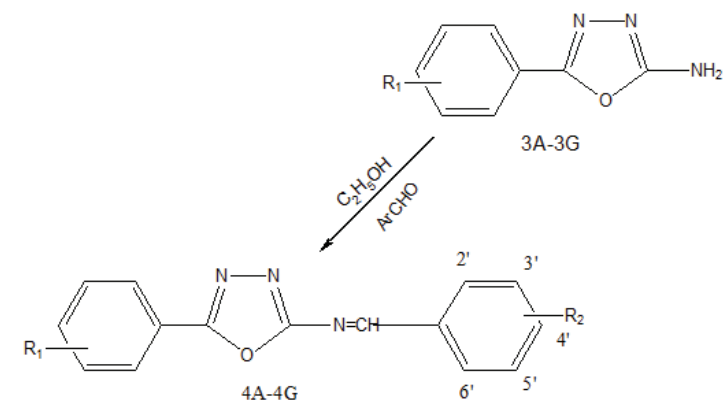

Scheme 1 Synthetic pathway for compounds 4A-4G

\begin{tabular}{ccc}
\hline Compound & $\mathbf{R}_{\mathbf{1}}$ & \multicolumn{1}{c}{$\mathbf{R}_{\mathbf{2}}$} \\
\hline $4 \mathrm{~A}$. & $4-\mathrm{OH}$, & $4^{\prime}-\mathrm{N}\left(\mathrm{CH}_{3}\right)_{2}$ \\
$4 \mathrm{~B}$ & $2-\mathrm{Cl}$ & $2^{\prime}-\mathrm{NO}_{2}$ \\
$4 \mathrm{C}$ & $3-\mathrm{Br}$ & $4^{\prime}-\mathrm{Cl}$ \\
$4 \mathrm{D}$ & $4-\mathrm{N}\left(\mathrm{CH}_{3}\right)_{2}$, & $4^{\prime}-\mathrm{N}\left(\mathrm{CH}_{3}\right)_{2}$ \\
$4 \mathrm{E}$ & $2-\mathrm{Cl}$, & $4^{\prime}-\mathrm{N}\left(\mathrm{CH}_{3}\right)_{2}$ \\
$4 \mathrm{~F}$ & $3-\mathrm{Br}$ & $4^{\prime}-\mathrm{OH}$ \\
$4 \mathrm{G}$ & $4-\mathrm{OCH}_{3}$, & $4^{\prime}-\mathrm{N}\left(\mathrm{CH}_{3}\right)_{2}$ \\
\hline
\end{tabular}


Compound:4A. [5-\{-4-Hydroxy-Phenyl)-2-imino-(4-dimethyl-amino-phenyl) 1, 3, 4- Oxadiazole] (C): M.P: $220-221-^{\circ}$ C. Yield: $70 \%$. Chemical formula: $\mathrm{C}_{17} \mathrm{H}_{16} \mathrm{O}_{2} \mathrm{~N}_{4}$ FT-IR $\left(\mathrm{cm}^{-1}\right)$ : 3452, $3283(\mathrm{ArC}-\mathrm{OH})$; 2913, 3068, 3154 (ArC-H); 1657 (C=N), 1250 (C-O-C), $1601(\mathrm{C}=\mathrm{C}), 1438,1509(\mathrm{~N}=\mathrm{CH}) . \quad{ }^{1} \mathrm{H}$ NMR $(300$ $\mathrm{MH}_{\mathrm{Z}}, \mathrm{DMSO}_{6}$ p p m): $\delta 10.08(\mathrm{~S}, 1 \mathrm{H}, \mathrm{N}=\mathrm{CH}): \delta 7.74$ $(\mathrm{d}, 2 \mathrm{H}, \mathrm{J}=9 \mathrm{~Hz}, \operatorname{ArH} 2,3) ; \delta 7.66(\mathrm{~d}, 2 \mathrm{H}, \mathrm{J}=9 \mathrm{~Hz}, \mathrm{ArH}$ $4,5,) ; \delta$ 2.93-2.85 ( d, 6H, N( $\left.\left.\mathrm{CH}_{2}\right)_{2}\right) ; \delta$ 7.13-7.06 (m, 4H, ArH); $\delta 9.91$ (s, 1H, O프). m/z: 310.50/308.50 $\left(\mathrm{M}^{+} / \mathrm{M}^{-}\right)$.

Compound: 4B. [5-\{(-2-Chloro-Phenyl)-2-imino-(2-nitro-phenyl)\}-1, 3, 4- Oxadiazole] : M. p: 214$216^{\circ}$ C. Yield: $80 \%$. Chemical formula: $\mathrm{C}_{15} \mathrm{H}_{9} \mathrm{O}_{3} \mathrm{~N}_{4} \mathrm{CI}$. FT-IR $\left(\mathrm{cm}^{-1}\right): 2991(\mathrm{ArCH}), 1515\left(\mathrm{ArC}-\mathrm{NO}_{2}\right)$ 742( ArC-CI), 1658 (C=N), 1280 (C-O-C), $1600(\dot{C}=\mathrm{C})$, 1426, $1515(\mathrm{~N}=\mathrm{CH}) .{ }^{1} \mathrm{H}$ NMR $\left(300 \mathrm{MHZ}, \mathrm{DMSO}_{6} \mathrm{p}\right.$ $\mathrm{p} \mathrm{m}): \delta$ 10.48.(S, 1H, N=CH); $\delta$ 6.57-7.46 (m, 4H, ArH 2'3' 5' 6'); $\delta$ 8.23-8.17 (m, 4H, ArH 2, 3, 4, 5,). m/z: $329.50 / 327.50\left(\mathrm{M}^{+} / \mathrm{M}^{-}\right)$.

Compound: 4C. [5-\{(3-Bromo-Phenyl)-2-imino(4-chloro-phenyl)\}-1, 3, 4-Oxadiazole]: M. p: 222$224^{\circ}$ C. Yield: $75 \%$. Chemical formula: $\mathrm{C}_{15} \mathrm{H}_{9} \mathrm{ON}_{3} \mathrm{BrCI}$. FT-IR $\left(\mathrm{cm}^{-1}\right)$ : 2991, $3068(\operatorname{ArC}-\mathrm{H}) ; 1682(\mathrm{C}=\mathrm{N}), 1220$ (C-O-C), $1600(\mathrm{C}=\mathrm{C})$ 1426, $1515(\mathrm{C}=\mathrm{NH}), 851,742$ (ArC-CI), 562, 627 (ArC-Br),. ${ }^{1} \mathrm{H}$ NMR (300 MHZ, DMSO d $_{6}$ p p m): $\delta 10.35(\mathrm{~S}, 1 \mathrm{H}, \mathrm{N}=\mathrm{CH}) ; \delta 7.52$ (d, 2H, J = 6Hz, ArH 2' 3'); $\delta 7.35$ (d, 2H, J=6Hz, ArH 5', 6'); $\delta 8.06$ (S 1H, ArH , 2); $\delta 7.78$ (s, 1H, ArH, 4);

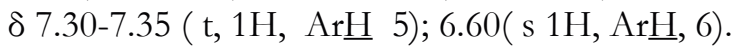

Compound: 4D. [5-\{-4-dimethyl amino-Phenyl)2-imino-(4-dimethyl amino-phenyl) 1, 3, 4- Oxadiazole]: M.P: $185-187^{\circ}$ C. yield- $70 \%$. Chemical formula: $\mathrm{C}_{19} \mathrm{H}_{21} \mathrm{ON}_{5}$. FT-IR $\left(\mathrm{cm}^{-1}\right): \quad 2938,3153(\mathrm{ArC}-\mathrm{H}) ; 1682$ $(\mathrm{C}=\mathrm{N}), 1221$ (C-O-C), 1558 (C=C), 1435, 1493 ( $\mathrm{N}=\mathrm{CH}) .{ }^{1} \mathrm{H}$ NMR (300 MHZ, DMSO d 6 p p m): $\delta 10.20(\mathrm{~S}, 1 \mathrm{H}, \mathrm{N}=\mathrm{CH}) ; \delta$ 2.96-2.93 ( d, 6H, N $\left.\left(\mathrm{CH}_{2}\right)_{2}\right)$; $\delta 3.34\left(\mathrm{~s}, 6 \mathrm{H}, \mathrm{N}\left(\mathrm{CH}_{2}\right)_{2}\right) ; \delta 6.79(\mathrm{~d}, 2 \mathrm{H}, \mathrm{J}=9 \mathrm{~Hz}$, ArH 2,3$) ; \delta 6.70(\mathrm{~d}, 2 \mathrm{H}, \mathrm{J}=9 \mathrm{~Hz}, \operatorname{ArH} 5,6) ; \delta 7.56-$ 748.(m, 4H, ArH 2', 3', 4', 5',).

Compound: 4E. [5-\{ 2 Chloro-Phenyl)-2-imino(4-dimethylamino-phenyl) 1, 3, 4- xadiazole] : M.P: $173-175^{-\mathrm{O}}$ C. Yield: $61 \%$. Chemical formula: $\mathrm{C}_{17} \mathrm{H}_{15}$ $\mathrm{ON}_{4}$ CI. FT-IR $\left.\left(\mathrm{cm}^{1}\right)^{1}\right): 3134(\mathrm{ArC}-\mathrm{H}), 1651(\mathrm{C}=\mathrm{N})$, 1253 (C-O-C), 1507 (C=C), 1439, 1357 ( $\mathrm{N}=\mathrm{CH})$, 765(ArC-Cl). ${ }^{1} \mathrm{H}$ NMR (300 MHZ, DMSO d 6 p p m): $\delta 10.50(\mathrm{~S}, 1 \mathrm{H}, \mathrm{N}=\mathrm{CH}) ; \delta 8.23-8.18(\mathrm{~m}, 4 \mathrm{H}, \operatorname{Ar} \underline{\mathrm{H}} 3$, 4, 5, 6); $\delta 7.69$ (d, 2H, J=6Hz, ArH 2', 3' ); $\delta 7.35$ (d, $\left.2 \mathrm{H}, \mathrm{J}=6 \mathrm{~Hz}, \operatorname{Ar} \underline{\mathrm{H}} 5,6^{\prime}\right) ; \delta 3.04$ ( s, 6H, N($\left.\left(\mathrm{CH}_{3}\right)_{2}\right) . \mathrm{m} / \mathrm{z}$ : 327.50/325.50( $\left.\mathrm{M}^{+} / \mathrm{M}^{-}\right)$.

Compound: 4F. [5-\{( 3-Bromo-Phenyl)-2-imino(4-hydroxy-phenyl)\}-1, 3, 4-Oxadiazole]: M. p: 222- $224^{\circ}$ C. Yield: $55 \%$. Chemical formula: $\mathrm{C}_{15} \mathrm{H}_{10} \mathrm{O}_{2} \mathrm{~N}_{3} \mathrm{Br}$. FT-IR $\left(\mathrm{cm}^{-1}\right): 3463$ (Ar-OH) 2984, 3062 (ArC-H); 1699 $(\mathrm{C}=\mathrm{N}), 1227(\mathrm{C}-\mathrm{O}-\mathrm{C}), 1584(\mathrm{C}=\mathrm{C}) 1471,1443(\mathrm{C}=\mathrm{NH})$, 559, 680 (ArC-Br), ${ }^{1} \mathrm{H}$ NMR (300 MHZ, DMSO d p p m): $\delta 10.36(\mathrm{~S}, 1 \mathrm{H}, \mathrm{N}=\mathrm{CH}) ; \delta 7.78-7.76(\mathrm{~d}, 2 \mathrm{H}$, $\left.\mathrm{J}=6 \mathrm{~Hz}, \operatorname{ArH} 2^{\prime} 3^{\prime}\right)$ ); $\delta$ 7.48-7.46 (d, 2H, ArH 5', 6',); $\delta 7.89(\mathrm{~S} 1 \mathrm{H}, \mathrm{ArH}, 2) ; \delta 7.71-7.69(\mathrm{~d}, 1 \mathrm{H}, \mathrm{J}=6 \mathrm{~Hz}$, $\mathrm{ArH}, 4) ; \delta$ 7.64-7.62 (d, 1H, J = 6Hz, ArH, 6); 7.36-7.31 (t 1H, ArH, 5); $\delta 8.06$ (s, IH, OH). m/z: 344.90/342.90 $\left(\mathrm{M}^{+} / \mathrm{M}^{-}\right)$.

Compound: 4G.[5-\{(4 Methoxy-Phenyl)-2-imino-(4amino-dimethyl-phenyl)\}-1, 3, 4- Oxadiazole]: M. p: $218-221{ }^{\circ}$ C. yield- $71 \%$. Chemical formula: $\mathrm{C}_{18} \mathrm{H}_{18}$ $\mathrm{O}_{2} \mathrm{~N}_{4}$.. FT-IR $\left(\mathrm{cm}^{-1}\right)$ : $3111(\mathrm{ArCH}), 1657(\mathrm{C}=\mathrm{N})$, 1077 (C-O-C), 1503 (C=O), 1563 (C=C), 1474, 1515 $(\mathrm{C}=\mathrm{NH}) .{ }^{1} \mathrm{H}$ NMR (300 MHZ, DMSO d $\left.\mathrm{d}_{6} \mathrm{p} \mathrm{m}\right)$ : $\delta$ 8.57. $(\mathrm{S}, 1 \mathrm{H}, \mathrm{N}=\mathrm{CH}): \delta 1.58\left(\mathrm{~s}, 3 \mathrm{H}, \mathrm{CH}_{3} \mathrm{O}\right) ; \delta 3.84-3.93$ $\left(\mathrm{d}, 6 \mathrm{H}, \mathrm{N}\left(\mathrm{CH}_{3}\right)_{2}\right) ; \delta 6.98\left(\mathrm{~d}, 2 \mathrm{H}, \mathrm{J}=9 \mathrm{~Hz}, \operatorname{ArH} 2^{\prime} 3^{\prime}\right)$; $\delta 6.92(\mathrm{~d}, 2 \mathrm{H}, \mathrm{J}=9 \mathrm{~Hz} \operatorname{ArH} 5$, 6' ); $\delta 7.57(\mathrm{~d}, 2 \mathrm{H}$, $\mathrm{J}=9 \mathrm{~Hz}, \operatorname{ArH~2,~3,~);~} \delta 7.50$ (d, 2H, J=Hz, ArH 5, 6,). $\mathrm{m} / \mathrm{z}: 323 / 321\left(\mathrm{M}^{+} / \mathrm{M}^{-}\right)$.

\section{Biological Experimental Section}

\section{Animals}

Studies were carried out using male Swiss albino mice of about 8 weeks of age with an average body weight of $18-20 \mathrm{~g}$. The animals were obtained from animal supplier Rita Ghosh, Kolkata, India. They were grouped and housed in polyacrylic cages and maintained under standard laboratory conditions (temperature $30^{\circ} \mathrm{C}$ ) with dark and light cycle (12/12h) and fed standard pellet diet, fresh water ad libitum. The mice were acclimatized to laboratory condition for 10 days before commencement of the experiment. All procedures described were reviewed and approved by the University Animals Ethical Committee. The recommendations of Jadavpur University Institutional Animal Ethics Committee [Committee for the Purpose of Control and Supervision of Experiment on Animals (CPCSEA registration. no. 0367/01/C/CPCSEA) India for the care and use of laboratory animals were strictly followed throughout the study and these were in accordance with the NIH (USA) guidelines.

\section{Tumor cell}

A tumor cell used for anticancer activity is EAC (Ehrlich Ascites Carcinoma) cells originated from human breast carcinoma. It is an undifferentiated tumor, which has lost its epithelial character. Ehrlich Ascites Carcinoma (EAC) cells were obtained from Chittaranjan National Cancer Institute, Kolkata, India. The (EAC) cells were maintained in vivo in Swiss albino mice by intra 
peritoneal inoculation of $2 \times 10^{6}$ cells/ mouse after 10 days. EAC cells of 9 days old were used for screening of the compounds.

\section{Experimental procedure}

Male Swiss albino mice of 8 weeks old with an average body weight of 18 to $20 \mathrm{~g}$ were used. All mice were kept on basal metabolic diet with water ad libitum. Male Swiss albino mice were divided into 10 groups $(\mathrm{n}=12)$. EAC cells are collected from the donor mice and are suspended in sterile isotonic solution $(0.9 \% \mathrm{w} / \mathrm{v} \mathrm{NaCl})$. The numbers of tumor cells per $\mathrm{ml}$ of this suspension are counted under microscope with the help of hemocytometer. All the groups were treated with EAC cells ( $0.2 \mathrm{ml}$ of $2 \times 10^{6}$ cells/mouse) intraperitoneally except the normal group. This was taken as day zero. In this instance, the tumor cells multiply relatively freely within the peritoneal cavity and ascites develops. A day of incubation allows for establishing the disease in the body before starting the drug administration. On the first day, $5 \mathrm{ml} / \mathrm{kg}$ body weight of normal saline $(0.9 \% \mathrm{NaCl} \mathrm{W} / \mathrm{v})$ was administered in group I (Normal). Normal saline $5 \mathrm{ml} / \mathrm{kg}$; body weight per day was administered in-group II (EAC control). The synthesized compounds (4A-4G were administered at dose of 25, 20, 20, 25, 20, $20,25 \mathrm{mg} \mathrm{mg} / \mathrm{kg}$; body weight/day) and the standard drug 5-Fluorouracil (20 mg/kg; body weight/day) was administered in groups (III-IX) and (X) respectively for 7 days intraperitoneally at $24 \mathrm{hr}$ interval. Thus 7 doses of the drug are administered to each mouse in the test group. On the $9^{\text {th }}$ day food and water were with hold $18 \mathrm{hr}$ before the starting the testing operation. The weight of all the animals was recorded before they are sacrificed. The peritoneal cavity was dissected and by a syringe the ascitic fluid was withdrawn to a suitable volume, collected in sterile ice-cold saline and preserved in ice bath. The total number of living cells $/ \mathrm{ml}$ in the peritoneal fluid of 6 mice in a group was calculated. The fluid is sucked by adsorbent cotton. The weight of 6 mice after sacrifice was recorded and remaining animals kept for observation of life span of the hosts.

The evaluation of the test drug is made by comparing the cell count of the test with that of the control. The percentage inhibition of cell count is obtained by following expression: $(\mathrm{TCI})=(1-\mathrm{T} / \mathrm{C}) \times 100$, where $\mathbf{T}$ is the average number of Ascitic cells $/ \mathrm{ml}$ in test animals, $\mathrm{C}$ is the average number of the Ascitic cells $/ \mathrm{ml}$ in control animals.

The anti-tumor activity of the compounds was measured in EAC animals with respect to the following parameters such as: Body weight, Tumor weight, Tumor cell count, Tumor growth response, Tumor volume,
Viable and non viable tumor cell count, Mean survival time and percentage increase in life span, Hematological studies. ${ }^{19-23}$

Acute Toxicity study: Male Albino mice of 10 animals per group and weighting between 18-20g were administered with graded doses of $(50-300 \mathrm{mg} / \mathrm{kg}$, Body weight, i. p) of the synthesized compounds (4A-4G). Death of the animals was observed $48 \mathrm{~h}$ treatment of the administered synthesized (4A-4G) compounds. The toxicological effects were observed in terms of mortality and expressed as $\mathrm{LD}_{50}$ (Ghosh et al., 1984). During the experiment on above said dose regimen $50 \%$ death was observed of synthesized compounds( $4 \mathrm{~A}-4 \mathrm{G})$ respectively (250, 200, 200, 250, 2000, 200, 250mg/kg, Body weight, i. p). From present study it could be concluded that synthesizes compounds ( $4 \mathrm{~A}-4 \mathrm{G})$ were safe unto 25 , $20,20,25,20,20,25 \mathrm{mg} / \mathrm{kg}$ body weight i. p.

\section{RESULT AND DISCUSSION}

Cancer is a pathological state where uncontrolled proliferation of the cancer cells is found. The anticancer properties of the synthesized compounds were evaluated by measuring their ability to inhibit cancer cell growth in ascitic fluid of Swiss albino mice. Percentage tumor weight inhibition (\% TWI) and percentage inhibition of ascitic cells or percentage of tumor cell count inhibition (\%TCI) were measured on treated EAC cells when compared to untreated control cells. Compounds $(4 \mathrm{~A}-4 \mathrm{G})$ having anticancer potential are shown in the Table 1. Among all the test compounds, compound 4E exhibited highest tumor weight inhibition $(73.15 \%)$ and tumor cell count inhibition (65.07\%) at the dose of $20 \mathrm{mg} / \mathrm{kg}$; body weight, (i.p.) as compared to control. Standard drug showed about 95.78\% tumor weight inhibition and $96.09 \%$ tumor cell count inhibition. The rest of the compounds showed $57.63 \%, 60.52 \%$, $60.52 \%, 62.63 \%, 62.63 \%$ and $63.68 \%$ of $\%$ TWI and $39.35 \%, 50.41 \%, 52.00 \%, 57.01 \%, 58.87 \%$ and $60.17 \%$ of $\%$ TCI respectively. According to the standard of National Cancer Institute, a substance is considered active if it exhibits the tumor growth inhibition of $50 \%$. All the tested compounds were found to show inhibition of tumor growth above $50 \%$ (except compound 4D) which supports the efficacy of the oxadiazole derivatives to serve as potent anti cancer agents against EAC cells.

In EAC bearing mice a regular rapid increase in ascites tumor volume was observed. Ascites fluid is considered to be direct nutritional source for tumor cells and a rapid increase in ascites fluid with tumor growth would be a means to meet the nutritional requirement of tumor 


\begin{tabular}{|c|c|c|c|c|c|c|}
\hline \multicolumn{6}{|c|}{ Table 1: Results of anticancer activity of the tested (A-G) compounds on \% TWI and \%TCI. } \\
\hline Group & Compounds & $\begin{array}{c}\text { Dose of drug } \\
\text { (mg /kg) }\end{array}$ & $\begin{array}{c}\text { Avg tumor weight } \\
\text { (g) }\end{array}$ & $\%$ TWI & $\begin{array}{c}\text { Avg cell count } \\
\text { (Number) }\end{array}$ & $\% \mathrm{TCI}$ \\
\hline I & Normal Control & ----- & ---- & --- & -- & ----- \\
\hline II & Induced control & ----- & 1.90 & 0.00 & $79.96 \pm 0.28$ & 0.00 \\
\hline III & A & 25 & $0.75 \pm 0.00^{*}$ & 60.52 & $38.38 \pm 0.51^{*}$ & 52.00 \\
\hline IV & B & 25 & $0.71 \pm 0.00^{*}$ & 62.63 & $34.35 \pm 0.53^{*}$ & 57.01 \\
\hline V & C & 25 & $0.75 \pm 0.00^{*}$ & 60.52 & $31.86 \pm 0.43^{*}$ & 60.15 \\
\hline VI & D & 25 & $0.81 \pm 0.00^{*}$ & 57.63 & $52.49 \pm 0.62^{*}$ & 39.35 \\
\hline VII & E & 25 & $0.51 \pm 0.00^{*}$ & 73.15 & $27.96 \pm 0.51^{*}$ & 65.07 \\
\hline VIII & F & 25 & $0.69 \pm 0.00^{*}$ & 63.68 & $32.88 \pm 0.48^{*}$ & 58.87 \\
\hline IX & G & 25 & $0.71 \pm 0.00^{*}$ & 62.63 & $39.65 \pm 0.25^{*}$ & 50.41 \\
\hline X & 5-Fluorouracil & 20 & ---- & 95.78 & ---- & 96.09 \\
\hline
\end{tabular}

Value are Mean \pm SEM. $\mathrm{n}=6$ animal in each group. ${ }^{*} \mathrm{P}<0.05$ is considered significant when III, IV, V, VI, VII, VIII, IX, groups were compared with group II. (When considered both Avg Tumor weight and Avg Cell count).

cells. $^{23,24}$ This might be the possible reason that the EAC cell-bearing mice (group II) showed a significant increase in body weight as compared with the normal mice in group-I (negative control).

5-Flurouracil treated group and test compounds (4A-4G) treated groups showed a significant $(\mathrm{p}<0.001)$ reduction in the body weight of EAC cell-bearing mice when compared with EAC control. The drugs decreased the tumor volume, packed cell volume, viable cell count and increased the life span, percentage of trypan blue positive stained dead cells in tumor bearing mice (Table 2).

Results for the test compound indicate that there is decrease in the nutritional fluid volume, arresting the tumor growth and the prolongation of the life span of animals and might be act as antineoplastic agents.

A complete blood count provides detailed information about three types of blood cells: red blood cells (RBC), white blood cells (WBC) and platelets. These blood cells are made in the bone marrow. Furthermore, hematological characteristics have been widely used in the diagnosis of variety of diseases (like cancer) and pathologies induced by industrial compounds, drugs, dyes, heavy metals, pesticides and several others. ${ }^{25,26,28,29}$

$\mathrm{RBC}$ (known as erythrocytes) is very important for the transport of oxygen from the lungs to the tissues and hemoglobin concentration is directly correlated with the RBC count. This close correlation between erythrocyte count and haemoglobin concentration was also reported for other vertebrates including man. ${ }^{30}$

WBC formed in the bone marrow either enters the blood or migrates to key organs such as the spleen, lymph nodes, or gut. The increased number of leukocytes can occur abnormally as a result of an infection, cancer, or toxic chemical. Such increase of WBC may be due to the activation of the defense mechanism of animals and their immune system. ${ }^{27}$

Myelosuppression and anemia are the two major problems in cancer chemotherapy. ${ }^{24}$ (Price et al., 1958; Hogland HC et al., 1982) The anemia in tumor bearing mice is mainly due to reduction in RBC or hemoglobin percentage and increase in $\mathrm{WBC}$ and this may occur either due to iron deficiency or due to hemolytic or myelopathic conditions or due to cancer. Treatment with $(4 A-4 G)$ brought back significantly $(p<0.05)$ the hemoglobin $(\mathrm{Hb})$ content, $\mathrm{RBC}$ and $\mathrm{WBC}$ count more or less to normal levels. He differential count and the percentage of neutrophil was increased, while the lymphocytes count was decreased in synthesized compounds treated groups bearing EAC cell lines when compared with EAC control mice. Other parameters like HCT (\%), MCV (fl), MCH (Pg), MCHC (g/ dL), PLT $\left(10^{9} / \mathrm{L}\right)$ were showen in Table 3. This clearly indicates that synthesized $(4 \mathrm{~A}-4 \mathrm{G})$ compounds possess protective action on the hemopoietic system.

Carcinogenesis is associated with cirrhosis and cirrhosis correlates with primary liver disease. Liver is easily affected by various types of diseases, cancer being one of them. EAC easily affects the liver of mice. From the experiment the liver section of EAC treated control group was compared with normal, 5-Flurouracil and drug treated groups (4A-4G). The histopathological observations of test groups suggested normal architecture of liver tissue, less thick wall central vein $(\mathbf{C V})$, deformed necrosis of tissue $(\mathbf{N})$ and nucleus, parenchyma, hepatic cells were regenerated, which was damaged in EAC treated control group. (Figure 1A-10) 


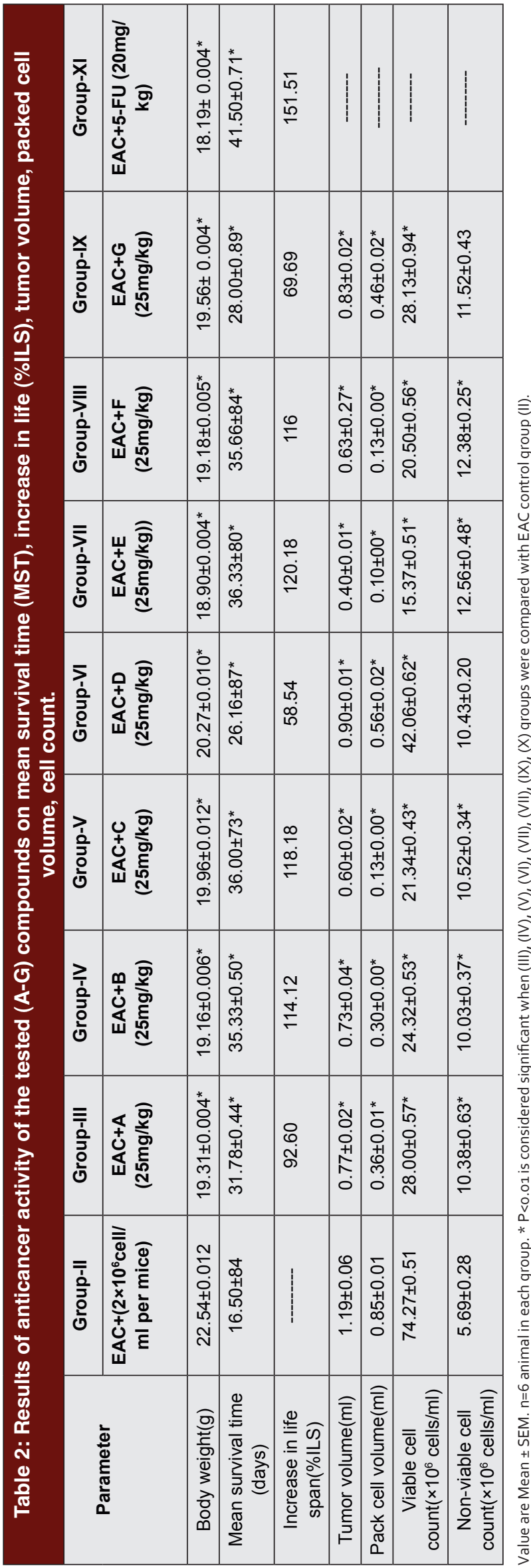

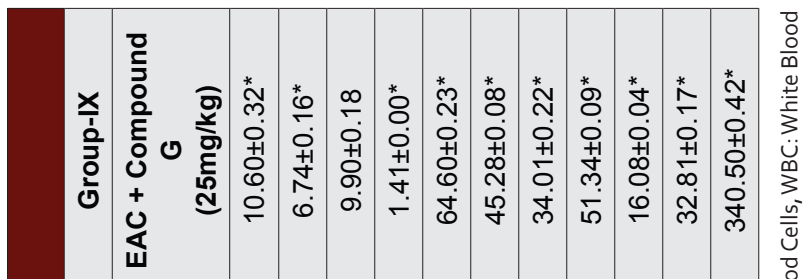

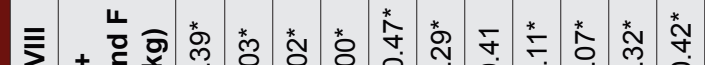

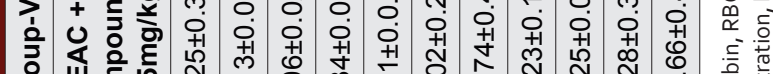
递它

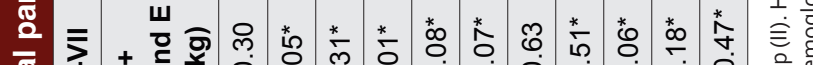

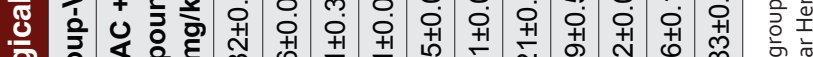
응 讨 密

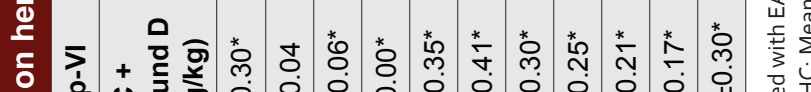

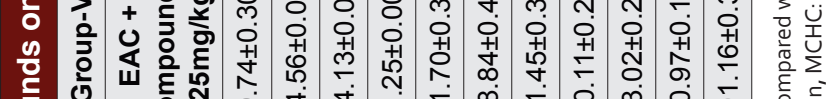
을

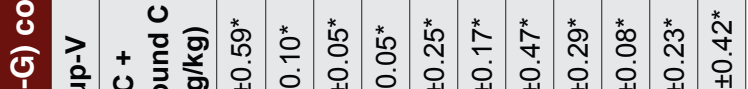

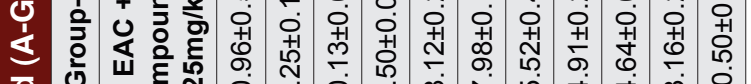

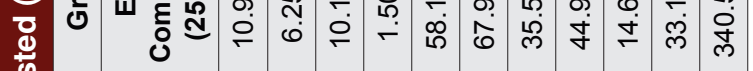

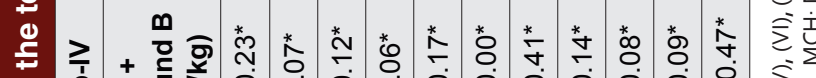

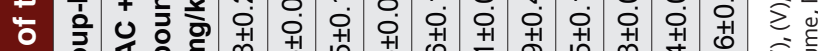

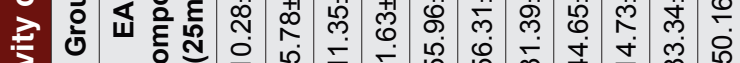
일

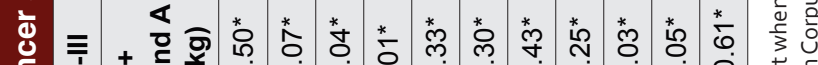
焉 忢

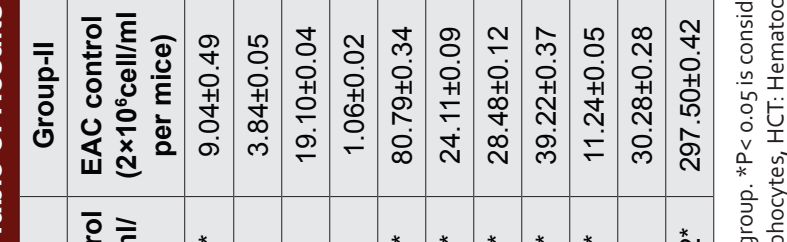

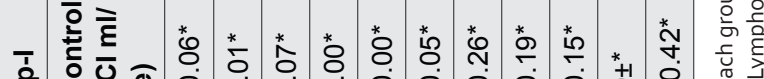

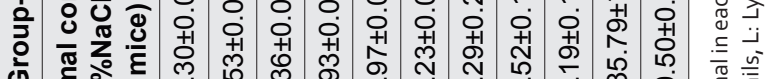

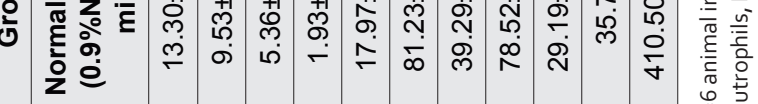

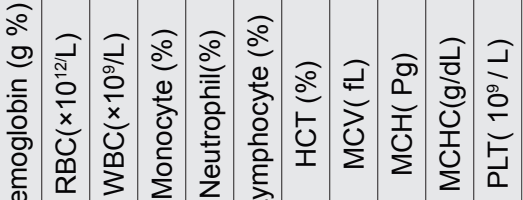

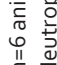
$\sum \ddot{z}$ $+1$ $\sum$

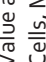




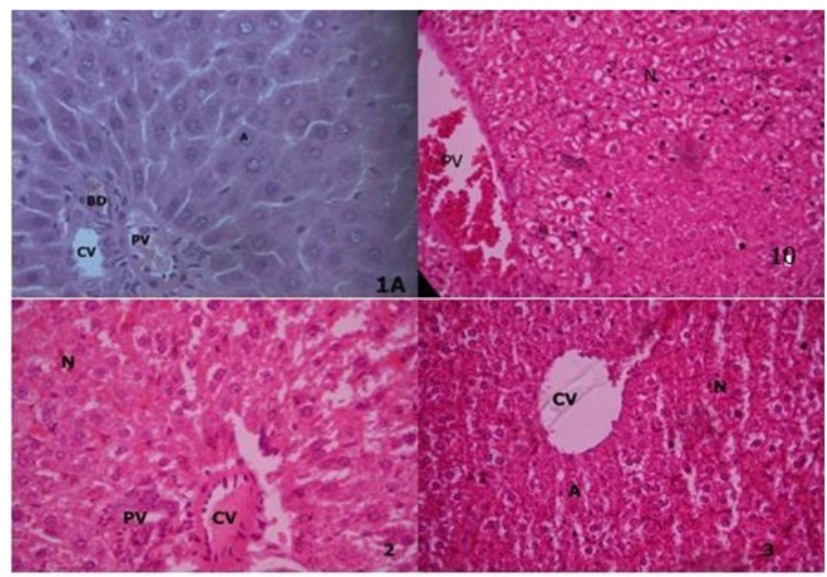

Fig. 1A, 2, 3, 10

Figure 1A: The liver section of the normal mice was composed of a number of lobules and hepatic tissue showing a thin walled central vein (CV) from which cords of hepatic cells radiate. Branches of the hepatic portal vein (PV), hepatic artery $(A)$ and bile ductules (BD) forming the portal triads are also seen $(\times 100)$.

Figure 2: Photomicrograph of mice liver in EAC treated with 5-Fluorouracil showing more or less normal structure of the liver tissue, showing thin wall central vein(CV), hepatic portal vein (PV) and large neoplastic hepatocytes (N) are regenerated look like to normal liver section $(\times 100)$.

Figure 10: Photomicrograph of mice liver in control group showing thick walled central vein (CV) plates of highly differentiated, large neoplastic hepatocytes $(\mathrm{N})$ (prominent nucleoli and finely granular cytoplasm) without discernible hepatic architecture $(\times 100)$.

\section{Structural features of the synthesized compounds for their antitumor activity}

In general, the anti cancer activity seemed to be dependent on the nature of the substituents rather the basic skeleton of the molecule. ${ }^{33}$ Within the Oxadiazole series it was noticed that the substituent at the position 5 had great influence on the anticancer activity. Substitution with various pharmacophore at this position may give rise to the novel molecules with enhanced anticancer properties.

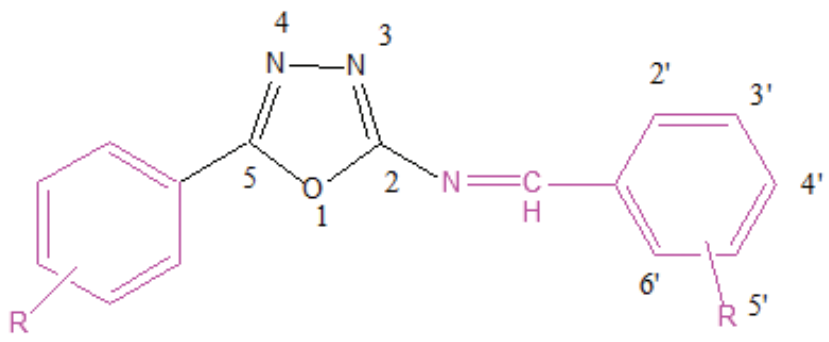

The Study indicates that groups like 4-hydroxy-phenyl (4A) 3-bromo phenyl(4C, 4F), 2-chloro phenyl(4B, 4E) substituent at 5-position and 2-nitrophenyl(4B), 4-chlorophenyl (4C), 4-hydroxy phenyl (4F) substituent at position 2 linking by im ino bridge to 1, 3, 4-oxadiazole showed significant anti-tumor activity.

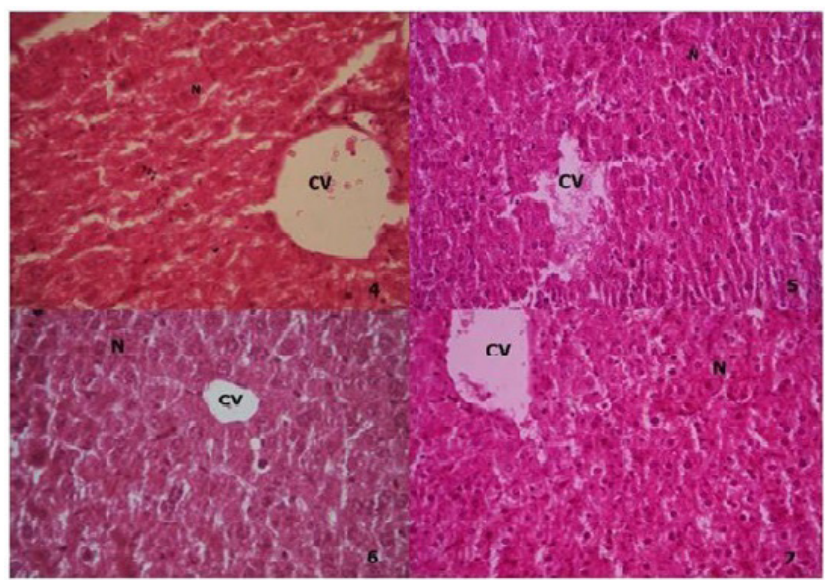

Fig. 4, 5, 6, 7

Figure: 3, 4, 5, 6, 7, 8 \& 9 Photomicrograph of mice liver in EAC treated with drugs (4A-4G) showing more or less structural damages of the liver tissue, showing damage central vein(CV), degenerated hepatocytes and deformed necrosis of tissue $(\mathrm{N})(\times 100)$.

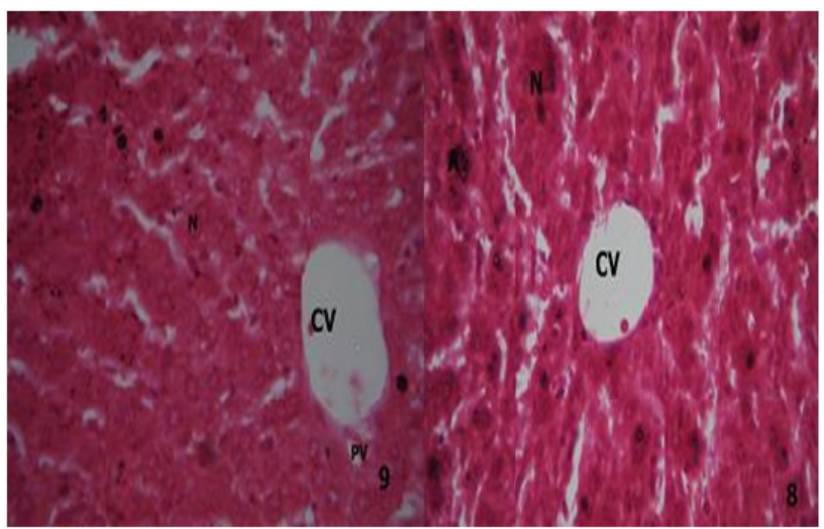

Fig: 8, 9

The activity of the compounds get increased due to the attachment of the phenyl ring with the substitution of the electron withdrawing/donating group at $5^{\text {th }}$ position of the Oxadiazole ring and also due to the presence of the $\mathrm{N}=\mathrm{CH}$ linked Schiff base side chains at 2 position. The exact mechanism of action of 1, 3, 4-Oxadiazole derivatives are still unknown. The probable mechanism may be due to multiple events, can increase percentage inhibition of ascitic cells or percentage of tumor cell count inhibition or act as decreasing the nutritional fluid volume or arresting the tumor growth or act as apoptosis inducer. A novel analog, 5-(3-chlorothiophen-2- yl)-3-(5-chloro-pyridin-2-yl)-1, 2, 4-oxadiazole was identified as a lead compound to induce apoptosis in vivo anticancer activity. ${ }^{31}$ Another novel series of 3, 5 -[1, 2, 4]-diaryl-oxadiazoles act as apoptosis-inducer in cancer treatment with no measurable effects on normal cells. ${ }^{32}$ Therefore the synthesized $1,3,4$ oxadiazole com- 
pounds with the above mentioned substituents could be a potential anticancer agent.

\section{CONCLUSION}

The synthesized compounds (4G-AG) showed significant result in different parameters of EAC bearing mice and markedly increase the average life span of experimental animals. From the present study, result indicate that the oxadiazole compounds can potentially be developed into useful anticancer agents or further work to develop or improve similar and related compounds and test them for a wide range of biological activity.

\section{ACKNOWLEDGEMENT}

One of the author (JS) acknowledges University Grants Commission (UGC) for providing support by a Start up Research Grant [No. F. 20-19(3)/2012(BSR)].

\section{CONFLICT OF INTEREST}

The authors have no conflict of interest.

\section{ABBREVIATIONS USED}

EAC: Ehrlich Ascites Carcinoma; 5FU: 5- Fluorouracil DMSO: Dimethyl sulfoxide; FTIR: Fourier Transform Infrared; HNMR: Proton Nuclear Magnetic Resonance; LCMS: Liquid Chromatography Mass Spectrometry; CPCSEA: The Committee for the Purpose of Control and Supervision of Experiments on Animals; LD50: Lethal Dose; TWI: Tumor Wight Inhibition; TCI: Tumor Cells Inhibition; HCT: Hematocrit; MCV: Mean Corpuscular Volume; MCH: Mean Corpuscular Hemoglobin; MCHC: Mean Corpuscular Hemoglobin Concentration; PLC: Platelet Count.

\section{REFERENCES}

1. Mesery ME El, Gayyar MM Al, Salem HA, Darweish MM, Mowafy AM El. Chemo preventive and renal protective effects for docosahexaenoic acid (DHA): implications of CRP and lipid peroxides. Cell. Division. 2009;4(1):61-7. https://doi.org/10.1186/1747-1028-4-6 PMid:19341447 PMCid:PMC2680397.

2. Nitha B, Meera CR, Janardhanan KK. Anti-inflammatory and antitumour activities of cultured mycelium of morel mushroom, Morchella esculenta. Current Sci. 2007;92(2):2-5.

3. Ahmed SA, Abdel-Rahman HM, Mahfouz NM, Mahmoud A, EL-Gendy. Nove 5-(2-hydroxyphenyl)-3-substituted-2, 3-dihydro-1, 3, 4- oxadiazole-2-thione derivatives: Promising anticancer agents. Bioorg Med Chem. 2006;14(4):123646. https://doi.org/10.1016/j.bmc.2005.09.053 PMid:16242340.

4. Rigo A, Couturier D. Studies on pyrrolidinones. Synthesis of $\mathrm{N}$ benzhydrylpyroglutamic. J Hetero Chem. 1985;22:925-30. https://doi. org/10.1002/jhet.5570220148.

5. Shashikant V, Bhandari KG, Bothara MK, Ajit R, Patil A, Aniket SP, Mokale VJ. Design, Synthesis and Evaluation of Anti-inflammatory, Analgesic and Ulcerogenicity studies of Novel S-Substituted phenacyl-1, 3, 4-oxadiazole- 2-thiol and Schiff bases of Diclofenac acid as Nonulcerogenic Derivatives. Bioorg Med Chem. 2008;16(4):1822-31. https://doi.org/10.1016/j. bmc.2007.11.014 PMid:18248993.

6. Katayoun A, Jessen, NM, English, Wang JY, Maliartchouk S, Kasibhatla S The discovery and mechanism of action of novel tumor-selective and apoptosis-inducing 3,5-diaryl-1, 2, 4-oxadiazole series using a chemical genetics approach. Mol Cancer Ther. 2005;4(5):761-71. https://doi. org/10.1158/1535-7163.MCT-04-0333 PMid:15897240.

7. Maria GM, Daniele Z, Luciano V, Maurizio F, Marco F, Pricl S, Scialinoc G, Banfic E. Antimycobacterial activity of new 3-substituted 5-(pyridin-4-yl)3H-1,3,4-oxadiazol-2-one and 2-thione Derivatives Preliminary molecular modeling investigations. Bioorg Med Chem. 2005;13(11):3797-09. https:// doi.org/10.1016/j.bmc.2005.03.013 PMid:15863006.

8. Guang F, Yang Z, Ming L, Xiang HQ. Synthesis of 5,7-Dimethyl-2-(5Substituted-1,3,4-Oxadiazole-2-yl)-Methylenethio-1,2,4-Triazolo[1,5-a] Pyrimidinesas Potential Fungicides. Chinese Chemical Lett. 2001;(12):877-80.

9. Aboraia AS, Abdel-Rahman HM, Mahfouz NM and EL-Gendy MA. Novel 5-(2-hydroxyphenyl)-3-substituted-2, 3-dihydro-1, 3, 4-oxadiazole-2-thione derivatives: Promising anticancer agents. Bioorg Med Chem. 2006;14(4):1236-46. https://doi.org/10.1016/j.bmc.2005.09.053 PMid:16242340.

10. Mishra L, Said MK, Itokawa H, Takeya K. Antitumor and antimicrobial activities of $\mathrm{Fe}$ (II)/Fe (III) complexes derived from some heterocyclic compounds. Bioorg Med Chem. 1995;3(9):1241-45. https://doi.org/10.1016/09680896(95)00095-X

11. Loetchutinat C, Chau F, Mankhetkorn S. Synthesis and Evaluation of 5-Aryl3-(4-hydroxyphenyl)-1, 3, 4-oxadiazole-2-(3H)-thiones as P-Glycoprotein Inhibitors. Chem Pharm Bull. 2003;51(6):728-30. https://doi.org/10.1248/ cpb.51.728 PMid:12808255.

12. Shia W, Qianb X, Songa G, Zhanga R, Lia R. Syntheses and insecticidal activities of novel 2-uorophenyl-5-aryl/cyclopropyl-1,3,4-oxadiazoles. J Fluorine Chem. 2000;106(2):173-79. https://doi.org/10.1016/S00221139(00)00323-7.

13. Yamada N, Kataoka Y, Nagami T, Hong S, Kawal S, Kuwano E. 5-Aryl-1, 3,4-oxadiazole-2-thiols as a New Series of trans-Cinnamate 4-Hydroxylase Inhibitors. J Pestic Sci. 2004;29(3):205-08. https://doi.org/10.1584/ jpestics.29.205.

14. Zarghi A, Hamedi S, Tootooni F, Amini B, Sharifi B, Faizi M, Abbas S, Abbas ST. Synthesis and Pharmacological Evaluation of New 2-Substituted-5-\{2-[(2 halobenzyl)thio)phenyl\}- 1,3,4-oxadiazoles as Anticonvulsant Agents. Sci. Pharm. 2008;76(2):185-01. https://doi.org/10.3797/scipharm.0803-10.

15. Rigo A, Lagrenee M. A simple and efficient procedure for synthesis of optically active 1, 3, 4-oxadiazole derivatives containing Lamino acid moieties. J Hetero Chem. 1999;36:1029-32.

16. Guimaraes CRW, Boger DL, Jorgensen WL. Elucidation of Fatty Acid Amide Hydrolase Inhibition by Potent $r$-Ketoheterocycle Derivatives from Monte Carlo Simulations. J Am Chem Soc. 2005;127(49):17377-384. https://doi. org/10.1021/ja055438j PMid:16332087.

17. Aboraia AS, Abdel-Rahman HM, Mahfouz NM, EL-Gendy MA. Novel 5-(2-hydroxyphenyl)-3-substituted-2, 3-dihydro-1, 3, 4-oxadiazole-2-thione derivatives: Promising anticancer agents. Bioorg Med Chem. 2006;14(4):1236-46. https://doi.org/10.1016/j.bmc.2005.09.053 PMid:16242340.

18. Khan MTH, Choudhury MI, Ranib KMKM, Atta-ur-Rahman. Structure-activity relationships of tyrosinase inhibitory combinatorial library of 2,5-disubstituted1,3,4-oxadiazole analogues. Bioorg Med Chem. 2005;13(10):3385-95. https://doi.org/10.1016/j.bmc.2005.03.012 PMid:15934142.

19. Hodnett EM, Dunn WJ. Structure Antitumor Activity Correlation of Some Schiff Bases. J Med Chem. 1970;13(4):768-69. https://doi.org/10.1021/ jm00298a054.

20. Mishra P, Rajak H, Mehta A. Synthesis of Schiff bases of 2-amino-5-aryl-1, 3, 4-oxadiazoles and their evaluation for antimicrobial activities. J Gen Appl Microbial. 2005;51(2):133-41. https://doi.org/10.2323/jgam.51.133.

21. Sengupta P, Dash DK, Yeligar, VC, Murugesh K, Rajlingam D, Singh J, Maity TK. Evaluation of Anticancer Activity of some 1, 3, 4-oxadiazole derivatives. Indian J Med Chem. 2008;47(3):460-62.

22. Gupta M, Mazumder UK, Haldar PK, Kandar CC, Manikandan L, Senthil GP. Anticancer Activity of Indigofera aspalathoides and Wedelia calendulaceae in Swiss Albino Mice. Iranian J Pharma Res. 2007;(6):141-45. 
23. Gupta M, Mazumdar UK. Antineoplastic activities of MT81 and its structural analogue in Ehrlich Ascites Carcinoma-bearing swiss albino mice. Oxida Med and Cellular Long. 2010;3(1):61-70. https://doi.org/10.4161/oxim.3.1.10495 PMid:20716929 PMCid:PMC2835890.

24. Gupta M, Mazumdar UK, Sambathkumar R, Sivakumar T. Antitumor activity and antioxidant role of Bauhinia racemosa against Ehrlich Ascites Carcinoma in swiss albino mice". Acta Pharm Sinica. 2004;25:1070-76. PMid:15301742.

25. Latha PG, Panikkar KR. Inhibition of Chemical Carcinogenesis in Mice by Ixora Coccinea. Flowers Cancer Lett. 1998;130:197-02. https://doi. org/10.1016/S0304-3835(98)00140-2.

26. Shakoori A.R, Ali SS, Saleem MA. Effect of six months feeding of cypermethrin on the blood and liver of albino rats. J Biochem Toxicol. 1988;3(1):59-72. https://doi.org/10.1002/jbt.2570030107.

27. Mansour SA, Mossa AH, Heikal TM. Haematoxicity of a New Natural Insecticide "Spinosad" on Male Albino Rats Int. J Agri Biol. 2007;9(2):342-46.

28. Shakoori AR, Aslam $\mathrm{H}$, Sabir $\mathrm{H}$, Ali SS. Effect of prolonged administration of Insceticides (Cyhalothrin/Karate) on the blood and Liver of Rabbites. Folia Biologica. 1999;40:1-2.

29. El-Bakary AS, Abdel FF, Abdel G, Mohamed MS, Attia I. Effect of Dimethoate on some Haematological Parameters of Toad Bufo regularis. J King Saud Unvi Agric Sci. 1995;1:85-95.

\section{PICTORIAL ABSTRACT}

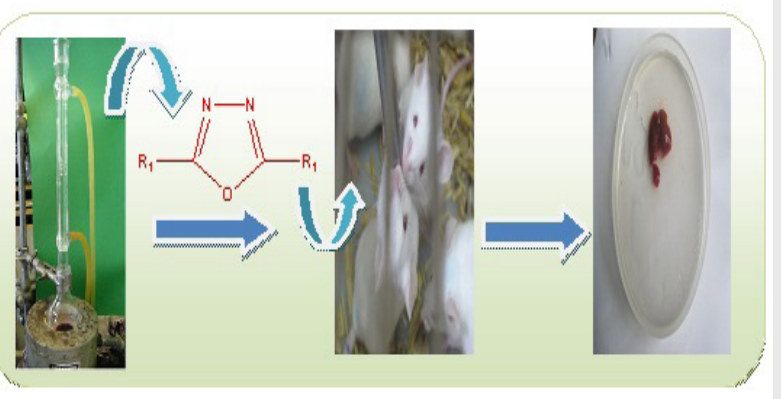

\section{About Authors}

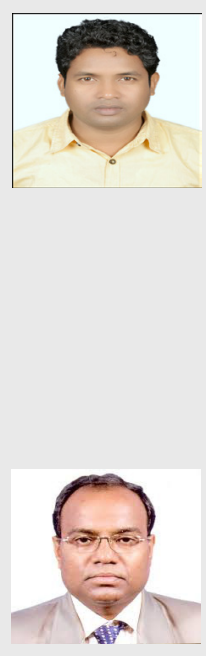

Dr. Jagadish Singh: Is working as Asst. Professor, Institute of Pharmaceutical sciences Guru Ghasidas Vishwavidyalaya, Bilaspur, C G (India). Research area (Interest): Synthetic Medicinal Chemistry and Photochemistry. Evaluation of Anticancer, Antidiabetic, Antimicrobial activities. $\mathrm{He}$ has published more than 10 international peer revived publications as well as 13 national publications.

Dr. Tapan Kumar Maity: Is working as Professor, Department of Pharmaceutical Technology, Jadavpur University. Research area (Interest): Synthetic Medicinal Chemistry and Photochemistry. He has more than 25 years of teaching and research experience which is highlighted in different national and international journals.
30. Sebrell WHJ, Harris RS. Tocopherols. In: The Vitamins: Chemistry, Physiology and Pathology. Academic Press, New York. 1972;16(5):166-17.

31. Nilantha S, Shailaja Kasibhatla BN, Pervin A, Wang Y, Claassen G, Tseng B, Drewe JSXC. Discovery of substituted 4-anilino-2-(2-pyridyl) pyrimidines as a new series of apoptosis inducers using a cell- and caspase-based high throughput screening assay. Part 1: Structure-activity relationshipsof the 4-anilino group. Bioorg Med Chem. 2006;14(23):7761-73. https://doi. org/10.1016/j.bmc.2006.08.002 PMid:16919962.

32. Katayoun AJ, Nicole ME, Wang YJ, Maliartchouk S, Archer SP, Qiu L, Brand R, Kemmerer J, Zhang HZ. The discovery and mechanism of action of novel tumor-selective and apoptosis-inducing 3, 5-diaryl-1,2,4-oxadiazole series using a chemical genetics approach. Mol Cancer Ther. 2005;4(5):135-37.

33. Adnan AK, El-Brollosy NR, A-Deeb OA, Elsayed EH, Tarek M, Ali Al, El-Emam. Synthesis, antimicrobial, and anti-inflammatory activities of novel 2-(1-adamantyl)-5-substituted-1, 3, 4-oxadiazoles and 2-(1-adamantylamino)5-substituted-1,3,4-thiadiazoles. Eur J Med Chem. 2007;42(2):235-42. https://doi.org/10.1016/j.ejmech.2006.10.003 PMid:17129641.

34. Oludotun AP, Udo EE, Mohammad E. Abdel-Hamid, Varghese R. Synthesis and antibacterial activity of novel 5-(4-methyl-1H-1, 2,3-triazole) methyl oxazolidinones. Eur J Med Chem. 2009;44(8):3217-27. https://doi. org/10.1016/j.ejmech.2009.03.024 PMid:19376613.

\section{SUMMARY}

- A series of 2,5-disubstituted 1, 3, 4-Oxadiazole derivatives (4A-4G) have been synthesized with the help of different aromatic Benzaldehyde and final compounds were characterized by FT-IR, ${ }^{1} \mathrm{H}$ NMR and Mass spectroscopy.

- The anticancer study was investigated against Ehrlich Ascites Carcinoma (EAC) bearing albino mice. The synthesized (4A-4G) compounds were administered intraperitoneally at dose of 20-25 $\mathrm{mg} / \mathrm{kg}$; body weight per day for 7 days after 24 hour of tumor inoculation in mice.

- The standard compound used was 5-FU $(20 \mathrm{mg} /$ kg; body, weight). Synthesized compounds (4A$4 \mathrm{G}$ ) remarkably decreased the body weight, tumor volume, packed cell volume, viable cell count and increased in tumor weight (\%) inhibition, tumor cells $(\%)$ inhibition, the life span, nonviable cell count of EAC tumor bearing mice when compared with the control group. The liver section of EAC treated control group (II) was compared with the drug treated groups (III-X).

- The histopathological observations of test groups suggested that normal architecture of liver nucleus, parenchyma, and hepatic cells were regenerated, which was damaged in EAC control group.

- All the synthesized compounds (4A-4G) showed significant anticancer activity in EAC bearing mice which encourages us to develop/improve similar other compounds and test them for their anticancer activity. 


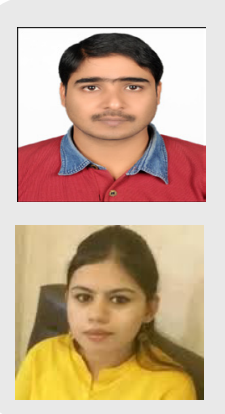

Dr. Partha Pratim Roy: Is working as Asst. Professor, Institute of Pharmaceutical sciences Guru Ghasidas Vishwavidyalaya, Bilaspur, C G (India). Research area (Interest): OSAR/ QSTR modeling and drug design. He has more than 25 international peer revived publications.

Miss Shalini bajaj: Is working as research fellow Institute of Pharmaceutical sciences Guru Ghasidas Vishwavidyalaya, Bilaspur, C G (India).

Cite this article: Roy PP, Bajaj S, Maity TK, Singh J. Synthesis and Evaluation of Anticancer Activity of 1, 3, 4-Oxadiazole Derivatives against Ehrlich Ascites Carcinoma Bearing Mice and Their Correlation with Histopathology of Liver. Indian J of Pharmaceutical Education and Research. 2017;51(2):260-9. 